\title{
斜面表層崩壊に対するミヤコザサ地下茥の補強効果
}

\author{
武田一夫 ${ }^{1} \cdot$ 山田哲司 ${ }^{1} \cdot$ 岡村昭彦 $^{1} \cdot$ 伊藤隆広 $^{1}$
}

\section{Effect of the Rhizome of Sasa nipponica on the Slope Reinforcement for Preventing Surface Failure}

\author{
TakedA, Kazuo ${ }^{1}$, Yamada, Tetsuji ${ }^{1}$, OKamura, Akihiko ${ }^{1}$ \\ and ITOH, Takahiro ${ }^{1}$
}

\begin{abstract}
要旨
ミヤコザサで覆われた斜面（ササ斜面）表層土の安定性を評価するため，地震によって 崩壊したとされる自然のササ斜面の現地調査と, ササ地下茎の引張り試験や土質試験など の室内試験を行った。測量結果から斜面は一体化した斜面表層崩壊の形態をしており, 表 層崩壊の安定解析モデルを設定して, 斜面に加わった地震の摇れや現地調査と室内試験の 結果を用いて安定計算を行った。その結果, 斜面単位幅断面のササ地下茎引張り力の関数 として表された地震時の安全率は, 1.0 前後の微妙な值をとり,ところどころで崩壊した地 震による斜面表層崩壊の状況を裏付けていることを示した。計算に用いた物理定数が妥当 な数值であると考元, 常時にも適用できると仮定して計算したところ, 常時の安全率はい ずれの場合も 1.26 以上になった。この計算式によると, ササのない斜面の安全率は土の強 度定数に支配されるが, 斜面単位幅断面のササ地下茎引張りカに対する安全率の増加はサ サ植生による補強効果を表している。また, 対象とする崩壊斜面の形状が半円形から斜面 に沿って長くなるほど，面積が小さいほど安全率は大きくなった。
\end{abstract}

\section{1. はじめに}

これからの道路づくりには，災害を起こさない， 緑化して景観に優れた，維持管理のいらない，低コ ストの法面保護工が求められている。著者らは, 寒 冷地の法面保護工を開発するため, 切土法面を対象 に凍上害の実態調査 ${ }^{16)}$ や凍上害を起こしにくい凍 上抑制法枠を提案・実証してきた ${ }^{18)}$ 。一方, 寒冷地の

キーワード：ササ(ミヤコザサ), 地震, 現地調査, 安全率, 斜面安定, 斜面表層崩壊

Key words : Dwarf bamboo (Sasa nipponica), Earthquake, Field investigation, Safety factor, Slope stabil. ity, Slope surface failure

1 (侏鴻池組

Konoike Construction Co. Ltd.
ミヤコザサ (Sasa nipponica) に覆われた斜面（ササ 斜面）では凍上害の発生が少なく，ササ地の熱環境 を調べたところ，葉層の断熱効果によって斜面の凍 結深や凍上量が減少し, 凍上害を抑制していること が示された ${ }^{17)}$ 。ところが, 実際に寒冷地で起こる斜 面崩壊は, 凍上害が直接的な原因で起こることもあ るが，法枠が凍上によって持ち上がって土留めや斜 面侵食防止の機能を失った斜面で融雪水や降雨など が原因で起こったり, 時に地震が原因で起こること もある。したがって，ササが崩壊しにくい斜面を形 成しているならば，凍上害を防ぐような熱環境を形 成しているだけでなく, ササ特有の水文学的性質や 力学的性質のあることが推測され, ササによって斜 面の安定化を図るためにはそれらの機構を明らかに する必要がある。 
この内, ササ地の力学的性質を評価するために, 本論文ではミヤコザサを対象として, 斜面安定を調 べた。ササに覆われた常時（地震時に対して地震の ない通常の状態をいう）の斜面の安定性は, 安定解 析モデルを設定して，調査や実験などで得た物理定 数を使って，安全率で評価することになる。しかし， 得られた安全率が妥当な值かどうか, 何らかの方法 で検証する必要がある。実際には，大がかりな実験 を伴うため困難なことが多い。そこで, 本研究では, 地震で崩壊したササ斜面に着目した。初めに，地震 で崩壊した土塊の解析モデルを設定し, 既知の地震 加速度扔よび室内試験と現地調査の結果から求めた 土塊の単位体積重量, すべり面の土の強度定数, サ サ地下茎の引張り力などの物理定数を使って, 地震 時の安全率を算出した。この安全率の妥当性を, 現 地の斜面崩壊の状況から論じた。次に, 地震時の計 算に用いた土の強度定数などの物理定数が常時にも 適用できると仮定して, 常時の安全率を算定し, 斜 面安定に及ぽすササ地下茎の補強効果について考察 した。

なお，本論を進める上で，ササ地下茎の強度に関 わる 4 つの用語, ササ地下茎の引張り力, 引張り荷 重, 地下茎の引張り強さ, 斜面単位幅断面の地下茎 引張り力を，その都度定義して用いた。

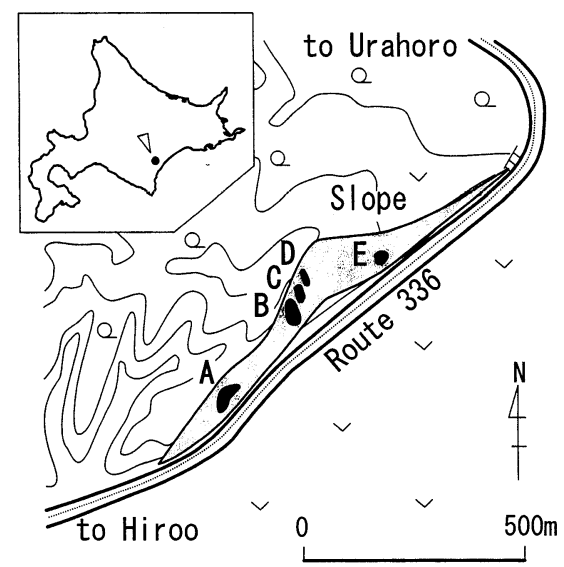

図 1 崩壊ササ斜面の模式図

Fig. 1 Schematic drawing of sporadically failed slope covered with dwarf bamboo

\section{2. ササ斜面の現地調査および室内試験}

2.1 調查概要と方法

\subsection{1 現地調査}

現地調査は, 地震で崩壊したササ斜面の測量調査 および植生構造と土質構造の調査からなる。調査地 は，北海道広尾郡大樹町美成の一般国道 336 号沿い にあるササに覆われた自然斜面で，新第三紀中新世 後期〜鮮新世前期の泥岩 (牛首別川層群) ${ }^{12)}$ で形成 された海岸段丘である(図 1)。この斜面は，全長が 約 $1 \mathrm{~km}$, 斜面長が $40 \sim 70 \mathrm{~m}$, 勾配が約 $40^{\circ}$, 方位が 南東向きである。地元民の話や航空写真から判断し て,1993 年 1 月 15 日に発生した釧路沖地震 (M 7.8) によるものとみられる崩壊が，斜面の 5 力所で発生 している。図 1 に示すように, 崩壊斜面を南西から 北東方向へ $\mathrm{A} \sim \mathrm{E}$ の記号でよぶことにする。これら の斜面は, 国道から $20 \mathrm{~m}$ 以上離れた場所にあり, 崩 壊によって交通障害をもたらさなかったため，当時 の状況がそのまま保たれている。その内の 1 つ，崩 壊斜面 $\mathrm{A}$ (以下，斜面 $\mathrm{A}$ とよぶ）を写真 1 に示した。

5 力所の崩壊斜面の内, 形状や面積の違いから A, $\mathrm{B}, \mathrm{E}$ の 3 斜面を選び，その外周に沿って基盤岩上を 数 $\mathrm{m} \sim 10$ 数 $\mathrm{m}$ おきに 11〜15 点と中央部数点で光 波測量を実施するとともに，崩壊部分の層厚を測定 した。また，崩壊斜面の上部と側部の破断部分で， 写真 2 に示すような長さ数十 $\mathrm{cm}$ の垂れ下がった地 下茥がみられた。ササの植生構造の調査は, 斜面 $\mathrm{A}$ に向かって上部と下部の右横約 $10 \mathrm{~m}$ 離れた場所 に, $1 \mathrm{~m}^{2}$ の採取地 2 力所(それぞれ採取地 1 , 採取地 2 とよぶ）を設定して行った。採取地を斜面に垂直に 深さ 50〜 $70 \mathrm{~cm}$ の泥岩からなる基盤層まで正方形

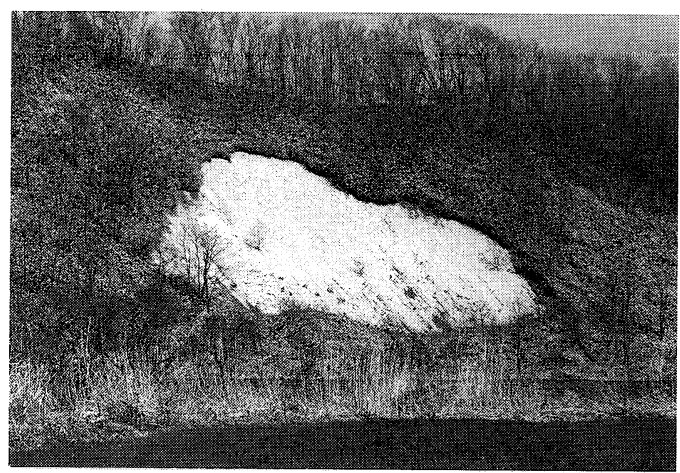

写真 1 地震によって崩壊した斜面 A

Photo. 1 Slope A failed by the earthquake 


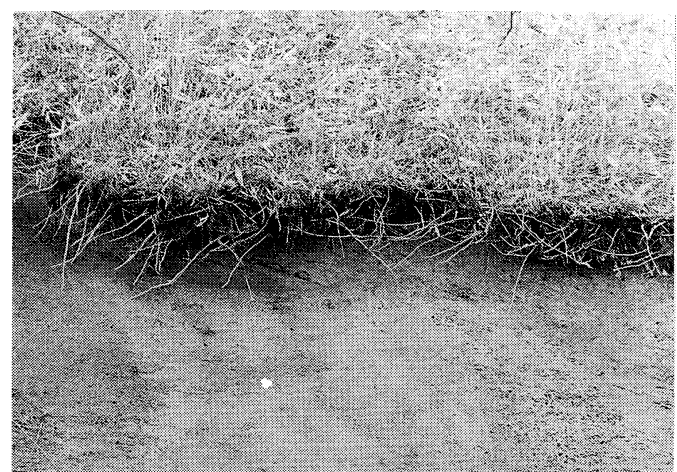

写真 2 崩壊斜面の破断部分の様子

Photo. 2 Broken part of the failed slope
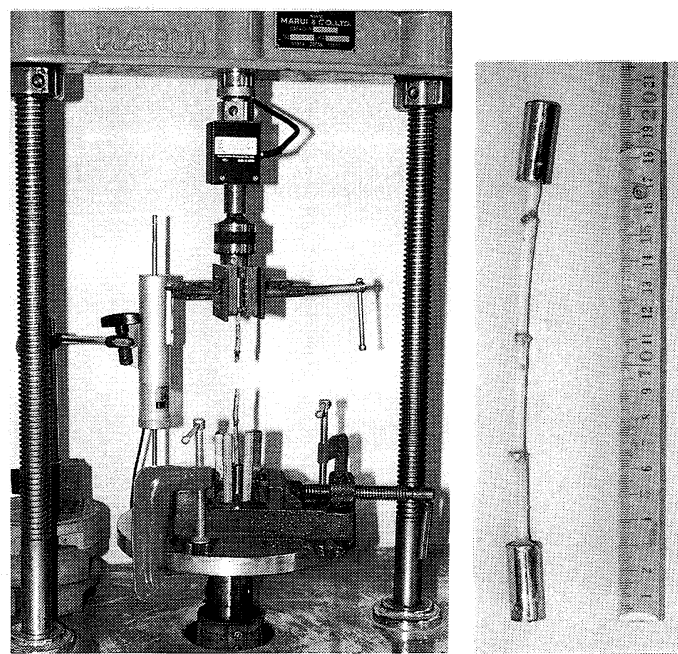

写真 3 ササ地下茎の引張り試験と供試体(右)

Photo. 3 Laboratory test on the tensile force of rhizome and the specimen (right)

に掘削してササを採取し，後述の表 2 に示す項目に ついて調査した。掘削後，採取地の斜面に向かって 上下左右の土層断面で，ササ地下茎の直径と深さを 測定し, 深さごとの地下茎の断面積分布を調べた。 また, 採取地 1 では土質調査を行い, 土質構成, 湿 潤密度分布, 含水比分布を得た。

\section{1 .2 室内試験}

室内試験では, ササ地下荎の引張り試験と土質試 験を行った。斜面の安定解析を行う上で, 斜面の崩 壊に関わる地下荎の引張り力（tensile force of rhizome, 単位： $\mathrm{N}$, 一般的なササ地下茎の力。後述の 式(1)の $T$ ) を調べた。地下茎は，採取地 1,2 から
表 1 崩壊斜面の調査結果

Table 1 Investigation results of failed slopes

\begin{tabular}{|c|c|c|c|}
\hline 崩壊斜面 Failed slopes & Slope A & Slope B & Slope E \\
\hline 斜面長 Slope length, m & 33 & 62 & 16 \\
\hline 斜面幅 Slope width, m & 45 & 21 & 13 \\
\hline 方 位 Direction, ${ }^{\circ *}$ & 135 & 135 & 160 \\
\hline 面 積 Area $S, \mathrm{~m}^{2}$ & 1,041 & 1,008 & 166 \\
\hline 平均勾配 Avg. gradient $\alpha$, & $\therefore \quad 40$ & 38 & 37 \\
\hline $\begin{array}{c}\text { 平均層厚 Avg. thickness } \\
\text { of sliding layer } H, \mathrm{~m}\end{array}$ & 0.6 & 0.6 & 0.6 \\
\hline
\end{tabular}

* 北方向を $0^{\circ}$ として右回りの方位角。Direction clockwise from the north.

採取し，湿潤状態で保管し供試体の作製に用いた。 地下茎の断面形状は，円形もしくは楕円形で，太い ものほど楕円形をしたものが多かった。平均直径 （長径と短径の平均）は 2〜 $7 \mathrm{~mm}$ の範囲にあり, 平 均 $4.5 \mathrm{~mm}$ であった。これらの中から平均直径が偏 らないように試料を選び，引張り試験に用いた。供 試体は，樹木根系の引張り試験と同様の方法 ${ }^{11)}$ で, 細根（直径 $2 \mathrm{~mm}$ 以下）を除去した後長さ約 $20 \mathrm{~cm}$ に切断し, 両端の表面を紙やすりで削って, 内径 1 $\mathrm{cm}$ のステンレス製パイプにエポキシ系樹脂で固定 して作製した (写真 3$)$ 。引張り試験では, 変位速度 約 $1 \mathrm{~mm} / \mathrm{s}$ で地下茎が破断するまで変位を与え続け た。このとき変位量と引張り荷重 (tensile load, 単 位：N, 引張り試験で地下茎に加える力）を測定し た。

一方，斜面崩壊のすべり面である強風化泥岩層か ら乱さない土試料を採取することが困難であったの で，土層から試験可能な粘性土を取り出して，含水 比 $84 \%$, 湿潤密度 $1.39 \mathrm{~g} / \mathrm{cm}^{3}$ で直径 $6 \mathrm{~cm}$, 高さ 2 $\mathrm{cm}$ の供試体を作製して，非排水条件下で在来型試 験機1 を用いた一面せん断試験を行った。

\section{2 調査および試験結果}

\section{2 .1 現地調査}

崩垍斜面の調査から得られた測量結果を表 1 亿示 した。また 3 つの崩壊斜面について, 斜面 $\mathrm{A}$ 前方の 平地に原点を設定し, 3 次元の $x y z$ 座標で測定点 を図 2-1(a), 図 2-2, 図 2-3 に示した。斜面 A, B の 面積は約 $1,000 \mathrm{~m}^{2}$ であったのに対して，斜面 $\mathrm{E} は$ $166 \mathrm{~m}^{2}$ c小規模である。斜面 $\mathrm{B}$ は他に比べて幅が 狭く斜面方向に長い斜面である。斜面の平均勾配は いずれも $37 \sim 40^{\circ}$ の範囲に, 崩壊斜面の土塊の平均 
(a)

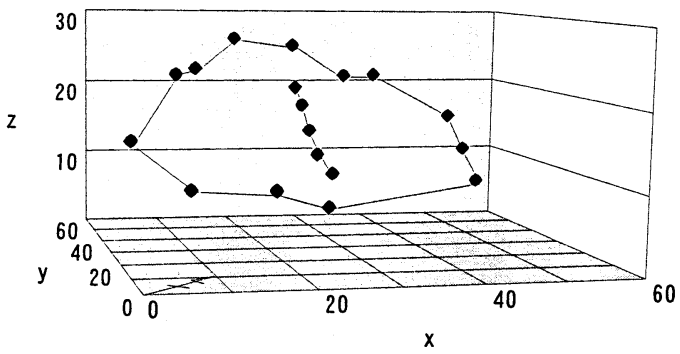

( b )

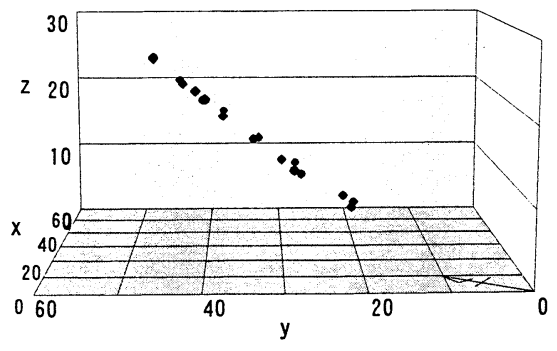

unit: $\mathrm{m}$

z

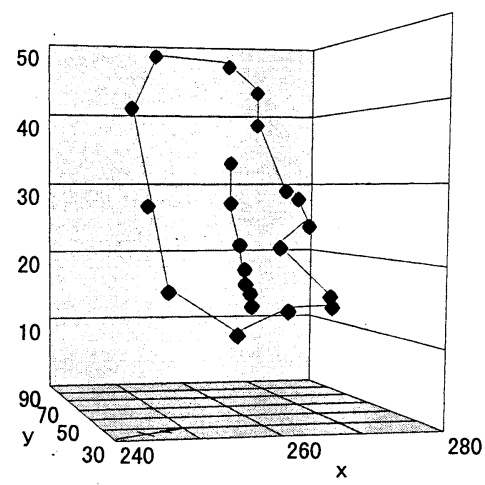

unit: $\mathrm{m}$

図 2-2 崩壊斜面 B の測量結果

Fig. 2-2 Result of field surveying for Slope B

層厚は $0.6 \mathrm{~m}$ であった。また, 斜面 $\mathrm{A}$ を $y$ 軸正面か ら見たものが図2-1(b)である。 $y$ 軸正面から見る と, 崩壊斜面上の点はほとんど直線状に分布し, 崩 壊部分の斜面長に対する厚さの割合が 0.018 であっ たことから，崩壊形態は円弧すべりとみるよりササ 層が土塊と一体化した斜面表層崩壊になってい $3^{3)}$ 。斜面 $\mathrm{B}, \mathrm{E}$ も, 斜面 $\mathrm{A}$ と同様の形態になってい

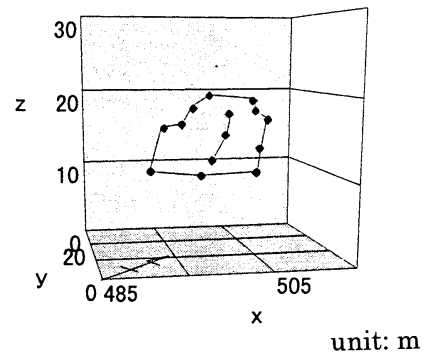

図 2-3 崩壊斜面 $\mathrm{E}$ の測量結果

Fig. 2-3 Result of field surveying for Slope E

表 2 ササ斜面の調査結果（斜面 $1 \mathrm{~m}^{2}$ あたり）

Table 2 Investigation results of dwarf bamboo in an area $1 \mathrm{~m}^{2}$ on the slope

\begin{tabular}{|c|c|c|}
\hline 調查・採取地 Investigated spot & Spot 1 & Spot 2 \\
\hline $\begin{array}{l}\text { 地上部の乾燥重量 Dry weight of } \\
\text { dwarf bamboo above the } \\
\text { ground, g }\end{array}$ & 704 & 593 \\
\hline
\end{tabular}

葉面積 Avg. area of leaf, $\mathrm{cm}^{2} / \quad 67.8 \quad 67.1$ leaf

秙 丈 Height of culm, cm $\quad 90 \quad 130$

稈密度 Culm density, culms $/ \mathrm{m}^{2} \quad 178 \quad 163$

地下部の乾燥重量 Dry weight of 1,547576 dwarf bamboo under the ground, $g$

地下茎の長さ Total length of rhi- $115.6 \quad 60.5$ zome, $m$

地下茎の乾燥重量 Dry weight of $1,278 \quad 536$ rhizome, g

地下茎の体積 Volume of rhizome， $\quad 1,750 \quad 980$ $\mathrm{cm}^{3}$

細根の乾燥重量 Dry weight of $269 \quad 40$ feeder root, $\mathrm{g}$

細根の体積 Volume of feeder $\quad 980 \quad 199$ root, $\mathrm{cm}^{3}$

最深地下菱 Max. depth of rhi- $45 \quad 63$ zome, cm

土層断面別の地下茥積算断面積合

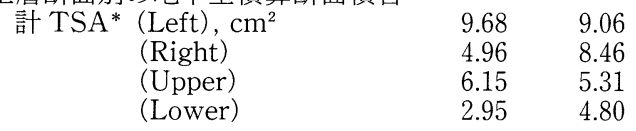

* TSA: total accumulated sectional area of rhizome per unit sectional width of a spot.

た。

表 2 に示すササ植生構造の調査結果によると, 秙 密度が $163 \sim 178$ 本 $/ \mathrm{m}^{2}, 1 \mathrm{~m}^{2}$ あたりの地下茎の長さ 

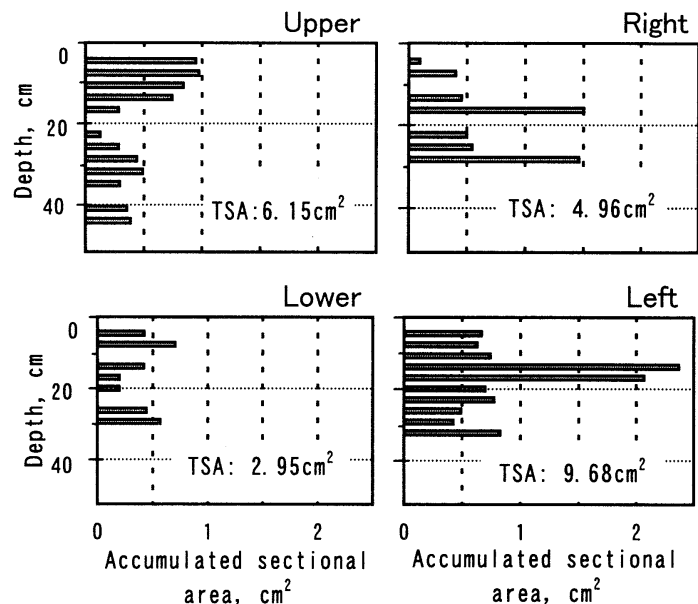

area, $\mathrm{cm}^{2}$

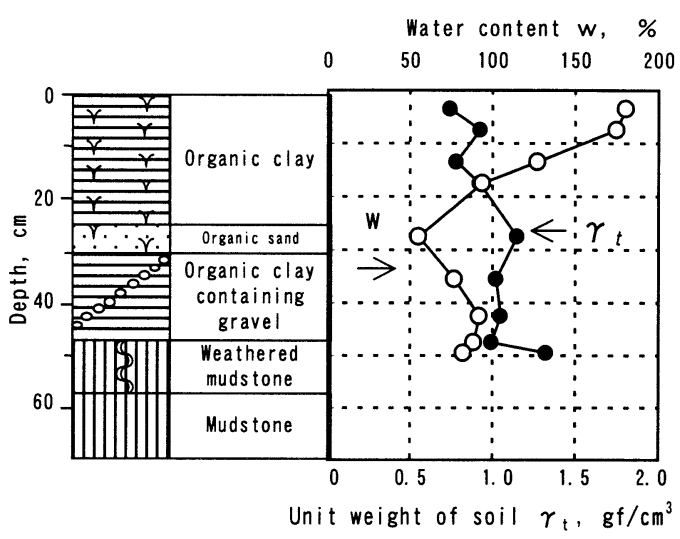

図 4 ササ斜面での土の含水比と単位体積重量の分布 (採取地 1)

Fig. 4 Profiles of water content and of unit weight of soil on the slope covered with dwarf bamboo (Spot 1)

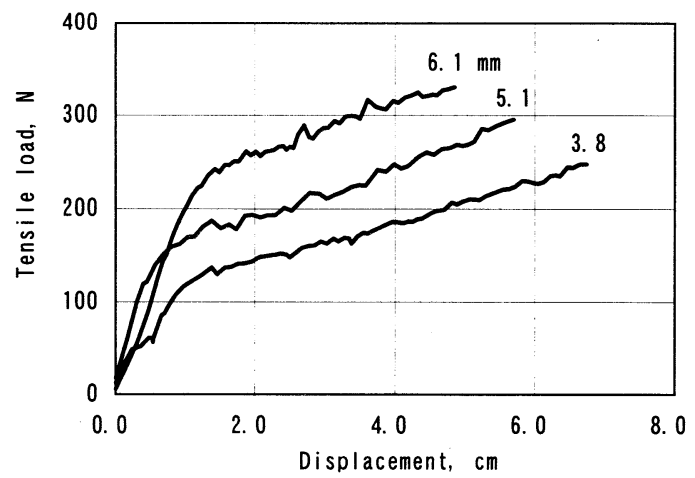

図 5 引張り荷重と変位量との関係（数字は地下茎の直 径)

Fig. 5 Relationship between tensile load and displacement of rhizome (Number: diameter of rhizome)

断面であった。採取地 1,2 いずれも斜面方向の上下 断面の和より水平方向の左右断面の和が大きくな り，この斜面では水平方向により多くの地下茎が生 育していることを示していた。

採取地 1 で行った土質調査から得た柱状眓を，図 4 に示した。地表面から深さ $25 \mathrm{~cm}$ までは有機物混 じり粘土, $25 \sim 30 \mathrm{~cm}$ は有機物混じり砂, $30 \sim 47 \mathrm{~cm}$ は碟混じり粘土, $47 \sim 57 \mathrm{~cm}$ は強風化泥岩, $57 \mathrm{~cm}$ 以深が基盤の泥岩であった。土の湿潤密度分布は地 表面付近と強風化泥岩層の一部を除いて $1.0 \mathrm{~g} / \mathrm{cm}^{3}$ 前後であり，含水比は上部粘性土が $180 \%$ で最も大 きく, 砂で $50 \%$ と最も小さく, 基盤上の強風化泥岩 で $90 \%$ と砂層より大きく, 基盤岩直上では地下水が
しみ出す状態にあった。

\section{2 .2 室内試験}

ササ地下茎の引張り試験は, 地下茎端部のステン レスパイプ部分で破断したものを除き，パイプの間 で破断した 53 例を有効な結果とした。破断は地下 茥の節部分で起こることも節間で起こることもあっ たが，どちらか一方で選択的に起こることはなく， 両方の場合を同一とみなして扱った。それらの結果 から, 平均直径の異なる代表的な 3 例の引張り荷重 と変位量との関係を, 図 5 に示した。いずれの試験 でも, 変位量 $1.0 \mathrm{~cm}$ 前後で引張り荷重に変化がみ 


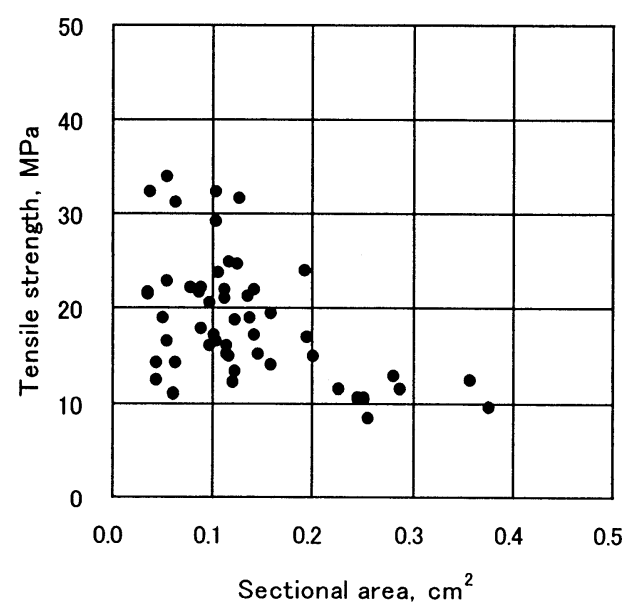

図 6 ササ地下茎の引張り強さと断面積との関係

Fig. 6 Relationship between tensile strength of rhizome and sectional area

られ，それ以上になると変位量の増加に伴って直線 的に引張り荷重が増加した後, 供試体は破断した。 破断時の変位量は，5〜 7 cm であった。

破断時の引張り荷重を単位断面積あたりに直した 引張り強さ (tensile strength of rhizome, 単位: $\mathrm{Pa}$ ，地下茎の単位断面積あたりの破断強度）と地下 茎の断面積との関係を，53例について図 6 に表し た。両者の間には明確な相関は認められなかった が, 断面積 $0.15 \mathrm{c} \mathrm{m}^{2}$ 以下の地下茎では, 引張り強 さは $10.8 \sim 33.8 \mathrm{MPa}$ と 3 倍以上の違いがあった。 これに対して, 断面積 $0.20 \mathrm{~cm}^{2}$ 以上では, $10 \mathrm{MPa}$ 近傍の值で，ほほ一定值を示した。全体では 8.4〜 $33.8 \mathrm{MPa}$ に分布した。

また, すべり面と思われる強風化泥岩層の粘性土 について，垂直荷重の異なる 4 例の一面せん断試験 の結果から，直線近似した相関係数は 0.98 で,土の 強度定数は粘着力が $2.35 \mathrm{kPa}$ で, 内部摩擦角が $27.5^{\circ}$ であった。

\section{3. ササ斜面の安定解析}

ササ斜面の安定解析モデルを設定し，現地調查と 室内試験の結果および地震情報を用いて地震時の解 析を行い, 結果を吟味した。次に, 常時の解析を行 った。

\section{1 地震の概要}

1993 年 1 月 15 日に発生した釧路沖地震は, 震源 に近い釧路を中心とした北海道東部地域で，道路，

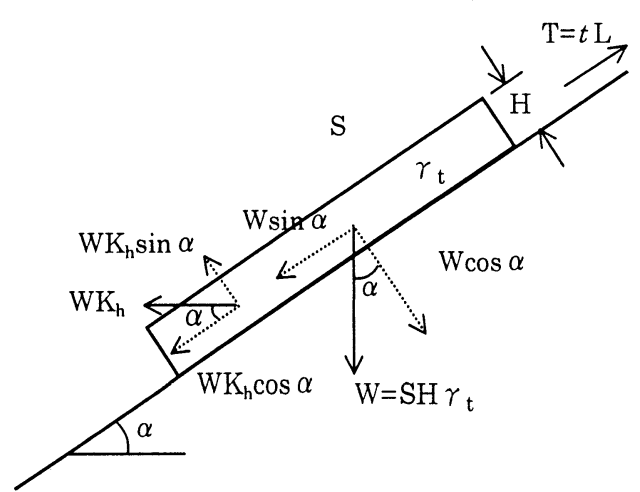

図 7 斜面安定の解析モデル

Fig. 7 Analysis model for slope stability

港湾，住宅，鉄道などに大きな被害をもたらした。 同地震による国道被災箇所の特徴として, 盛土部と 切土部の境界や片切片盛土の盛土側に被害が集中し ていることが報告されている ${ }^{13,19)}$ 。地震は, 現地の 南西約 $25 \mathrm{~km}$ にある広尾町役場 (北海道広尾郡広尾 町）での観測記録 ${ }^{10)}$ から, 南北方向の水平加速度 $328 \mathrm{gal}$, 東西方向の水平加速度 $328 \mathrm{gal}$, および上下 方向の垂直加速度 $203 \mathrm{gal}$ を当該斜面に与え, ササ 斜面の崩壊をもたらしたとみられる。

\section{2 安定解析の方法}

斜面安定に関与する既存の木本類根系モデルの根 系は, すべり面に垂直方向に伸張し, 根系のせん断 力がすべり面のせん断力を増加させる，いわゆるア ンカー効果として評価されてきた。今回, 現地調査 の結果から, 崩壊斜面は土塊層厚の薄く崩壊長さの 長い, 斜面表層崩壊の形態をしていることが示され た。しかも, 土塊層厚 $60 \mathrm{~cm}$ に対して, 地下茥の大 部分が地表面から斜面垂直方向に深さ $30 \mathrm{~cm}$ の範 囲に分布している。このため, 土塊のすべり面では 木本類根系とは異なり, 地下茎はほとんど関与して いないとみられる。むしろ, 崩壊土塊周辺の破断部 分で, その引張り力がすべり面に水平上方に抵抗力 として作用している。この点が斜面安定の機構上, 木本類根系モデルと異なる部分である。

安定解析をするために, 図 7 に示す一定の傾斜面 に沿う表層崩壊の解析モデルを設定した。安定計算 はモール・クーロン式による土のせん断強度で構成 される安全率の式で行うが，一般の土木工事ではす べりに対する土塊の安全率の不足分を補充するた め, 通常アンカー・杭・擁壁などで抵抗力を増加さ 
表 3 斜面安定解析に用いた数値

Table 3 Values used in the analysis for the slope stability

\begin{tabular}{|c|c|c|c|}
\hline 崩壞斜面 Failed slopes & Slope A & Slope B & Slope E \\
\hline 崩壊斜面の単位体積重量 Unit weight of failed slope $\gamma_{\mathrm{t}}, \mathrm{kN} / \mathrm{m}^{3}$ & 9.5 & 9.5 & 9.5 \\
\hline $\begin{array}{l}\text { 斜面単位断面幅のササ地下茎引張り強さ } \\
\text { Tensile force of rhizome per unit sectional width of slope } \\
\text { surface layer } t, \mathrm{kN} / \mathrm{m}\end{array}$ & $0.0,5.8,20.3$ & $0.0,5.8,20.3$ & $0.0,5.8,20.3$ \\
\hline $\begin{array}{l}\text { 崩買斜面周囲の破断長 Length of broken part around the failed } \\
\text { slope } L, \mathrm{~m}\end{array}$ & 73.1 & 83.0 & 29.0 \\
\hline すべり面の粘着力 Cohesion at the sliding surface $c, \mathrm{kPa}$ & 2.35 & 2.35 & 2.35 \\
\hline $\begin{array}{l}\text { すべり面の内部摩擦角 Internal friction angle at the sliding sur- } \\
\text { face } \phi,\end{array}$ & 27.5 & 27.5 & 27.5 \\
\hline 地震力 Ratio of horizontal seismic acceleration to gravity $K_{\mathrm{h}}$ & 0.335 & 0.335 & 0.335 \\
\hline
\end{tabular}

せる ${ }^{4,9)}$ 。この抵抗力を斜面の垂直成分と水平成分に 分割したとき，垂直成分は木本類根系モデルの根系 のせん断力に，水平成分はササ地下茥の引張り力に 対応する。そこで, 本モデルは, 地震による加速度 を考慮するとともに，この引張り力が崩壊斜面に沿 って発揮されて土塊のすべりに抵抗しているものを 考えた。地震時の表層崩壊は，実際にはかなり複雑 な現象であることが予想される。しかし，安定解析 では現象を単純化するため, 剛体の土塊が地下茥と いうワイヤーで斜面上方から引張られているときに 地震による水平力が働いて, ワイヤーが破断して表 層崩壊が発生するという状況を想定した。地下茎の 引張り力は, 調査で得られる情報の中から, 室内試 験で得た地下茥の引張り強さと単位土層断面にしめ る地下茎の断面積とから求めた，斜面単位幅断面の ササ地下茎引張り力 (tensile force of rhizome per unit sectional width of slope surface layer, 単位: $\mathrm{kN} / \mathrm{m}$ ，斜面幅 $1 \mathrm{~m}$ あたりのマット状になったササ 地下茎の引張り強度, 式(1)'の $t$ ) で表した。なお, ここでの引張り力は, ササ根系の細根(直径 $2 \mathrm{~mm}$ 以 下）の力も考えられるが，扱いを単純化するため地 下茎が根系を代表するものとみなした。また，すべ り面を基盤上の強風化泥岩層とした。

斜面単位幅断面のササ地下茥引張り力をパラメー ターとする安定計算は, 次式で行った。安全率 FS は,

$$
\begin{aligned}
F_{S} & =\frac{c \cdot S+\left(W \cdot \cos \alpha-W \cdot K_{\mathrm{h}} \cdot \sin \alpha\right) \cdot \tan \phi+T}{W \cdot \sin \alpha+W \cdot K_{\mathrm{h}} \cdot \cos \alpha} \\
& =\frac{L}{S \cdot H \cdot \gamma_{\mathrm{t}} \cdot\left(\sin \alpha+K_{\mathrm{h}} \cdot \cos \alpha\right)} t
\end{aligned}
$$

$$
+\frac{c+H \cdot \gamma_{\mathrm{t}}\left(\cos \alpha-K_{\mathrm{h}} \cdot \sin \alpha\right) \cdot \tan \phi}{H \cdot \gamma_{\mathrm{t}} \cdot\left(\sin \alpha+K_{\mathrm{h}} \cdot \cos \alpha\right)}
$$

ここで,

$c(\mathrm{kPa})$ : すべり面の粘着力

$S\left(\mathrm{~m}^{2}\right)$ ：崩壊斜面の面積

$H(\mathrm{~m})$ : 崩壊土塊の厚さ

$\gamma_{\mathrm{t}}\left(\mathrm{kN} / \mathrm{m}^{3}\right)$ : 単位体積重量

$W(\mathrm{t}):$ 崩壊土塊の重量 $\left(=S \cdot H \cdot \gamma_{\mathrm{t}}\right)$

$\alpha\left(^{\circ}\right)$ : 斜面の勾配

$K_{\mathrm{h}}:$ 水平震度係数 $\left(=0.335 ; K_{\mathrm{h}}=328 /\right.$ 980, 常時は $K_{\mathrm{h}}=0$, ここで 328 は水 平方向の加速度)

$\phi\left(^{\circ}\right)$ : すべり面の内部摩擦角

$t(\mathrm{kN} / \mathrm{m})$ : 斜面単位幅断面のササ地下茎引張り 方

$L(\mathrm{~m})$ ：ササ斜面（上部と側部）の破断長

$T(\mathrm{kN})$ : ササ地下菱の引張り力 $(=t \cdot L)$

で与えられる。

安定解析は 3 つの崩壊斜面について行った。解析 に用いた数值は, 表 1 の下部に示した崩壊斜面の面 積 $S$, 平均勾配 $\alpha$, 平均層厚 $H$, および表 3 に示し た 6 項目である。この内, 斜面 A でのササ斜面長さ $1 \mathrm{~m}$ あたり地下茎の積算断面積合計は, 図 3 に示す 4 断面の平均值 $5.9 \mathrm{~cm}^{2}$ とした。ササ地下茎の引張 り試験結果から引張り強さは 8.4 33.8 MPa であ るので, 斜面 $1 \mathrm{~m}$ 幅で発揮される引張り力 $t$ を $5.0 \sim 19.9 \mathrm{kN} / \mathrm{m}$ と算定した。崩壊斜面周囲の破断 長 $L$ は, 写真 2 が示すような地下茎の破断が確認さ れた斜面の上部と側部について測量で得られた長さ の合計を示した。ここで, 側部の地下茎は地震時に 伸長し柔軟な動きによってすべり方向と同じ方向に 
力を受けて破断したものとみなして，側部を上部と 同じように扱った。すべり面の強度定数は, 強風化 泥岩層 (深さ $47 \sim 57 \mathrm{~cm}$ ) に含まれる粘性土の一面せ ん断試験結果を用いた。

なお, 地震発生当時が 1 月中旬であり, 崩壊斜面 の表層土は部分的に凍結していた可能性がある。表 層土が数十 $\mathrm{cm}$ 凍結していたならば, 式(1)でササ地 下茎の引張り力や凍結に伴う土のせん断強度の増加 によって, 安全率も変わると予想される。しかし,

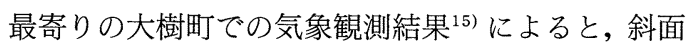
方位やササの植生条件を考慮して試算した凍結深は $6.8 \mathrm{~cm}$ になり崩壊土塊の厚さに比べて小さいので, 安定計算では土の凍結の影響は無視した。

\section{3 安定解析の結果}

地震時の 3 斜面について, 安全率 FS と斜面単位 幅断面のササ地下茎引張り力 $t$ との関係を図 8 に示 した。これらの直線は, 式(1)を式(1)'のように書き 換えると安全率が $t$ の関数で表され，引張り試験の 測定から得られた $t$ 範囲を太線で示した。はじめ に, 斜面 A について, 式(1)'の $t$ に対する安全率の 勾配（安全率の増加割合）は, ササによる斜面の補 強効果を表し，0.0137になった。安全率は $t$ の $0 \sim 16.6 \mathrm{kN} / \mathrm{m}$ で 1.0 以下となり, 斜面は崩壊する 危険な状態となる。特に, 地震時の太線範囲の安全 率は, ササの引張り力によって 1.0 前後の值となっ た。つぎに，斜面 $\mathrm{B}$ の地震時の安全率は， $t$ の $0.0 \sim 11.3 \mathrm{kN} / \mathrm{m}$ の範囲で 1.0 以下となり（図 8),

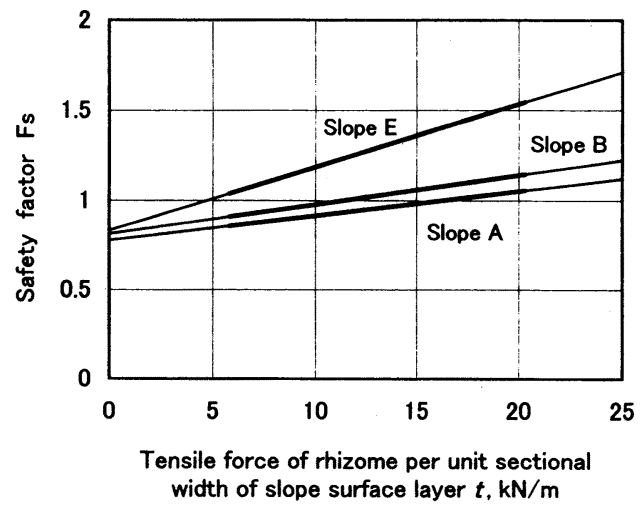

図 8 地震時の安全率と斜面単位幅断面のササ地下茥引 張り力との関係

Fig. 8 Relationship between safety factor during earthquake and tensile force of rhizome per unit sectional width of slope surface layer
ここでも地下茎の状態によっては崩壊の可能性を示 している。 $t$ に対する安全率の勾配は 0.0164 で, 斜 面 $\mathrm{A}$ に比べて大きくなった。また, 斜面 $\mathrm{E}$ の地震時 の安全率は $t$ の $0.0 \sim 4.8 \mathrm{kN} / \mathrm{m}$ の範囲で 1.0 以下 となった(図 8)。斜面 $\mathrm{E}$ の太線で示す安全率は, $t=$ $5.0 \mathrm{kN} / \mathrm{m}$ で 1.01 とわずかに 1.0 を上回ったが, 崩 壞の可能性を示す数值に変わりない。 $t$ に対する安 全率の勾配は,地震時 0.0352 となり他の 2 斜面に比 べてかなり大きくなった。

今回測量した 3 斜面で, 斜面単位幅断面のササ地 下茎引張り力のある範囲において, 地震時の安全率 が 1.0 前後の微妙な值をとることは, 実際の斜面に おいても室内試験時と同等の地下茎の引張り力が発 揮され，全長約 $1 \mathrm{~km}$ にわたる自然のサ专斜面でわ ずか数力所の崩壊がみられたことを反映している。 仮に，地震時の安全率が 1.0 よりかなり小さければ ササ斜面はさらに多くの場所で崩壊し, 逆に 1.0 よ りかなり大きければほとんど崩壊しなかったと予想 される。したがって, 安定解析で用いた数值は, 地 震時の斜面表層崩壞の現象を再現し，概ね妥当な値 とみることができる。

地震時の安定解析で用いた物理定数の妥当性を考 え, これらの定数が常時にも適用できると仮定し て, 常時の安定解析を行い, 結果を図 9, 表 4 にまと めた。崩壊斜面 $\mathrm{A} の$ 結果によると, 安全率は $t=$

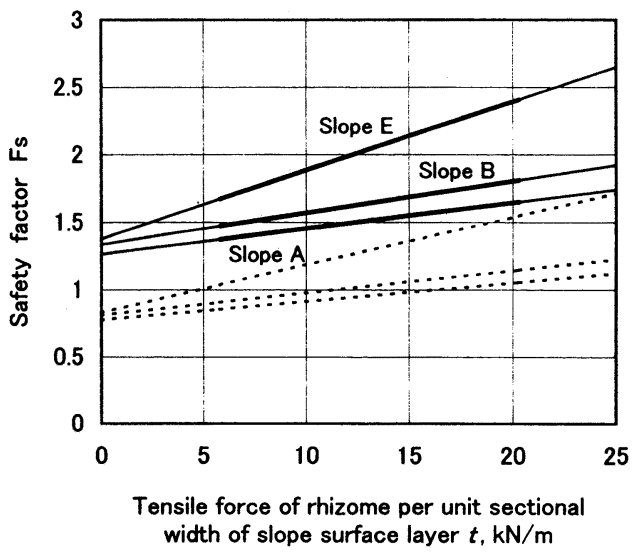

図 9 常時の安全率と斜面単位幅断面のササ地下茎引張 り方との関係。実線：常時, 点線：地震時。

Fig. 9 Relationship between safety factor at the static condition and tensile force of rhizome per unit sectional width of slope surface layer. solid line: static condition, dotted line: during earthquake. 
表 4 ササ斜面安定解析の結果

Table 4 Results of analysis for the stability of slope covered with dwarf bamboo

\begin{tabular}{clll}
\hline 崩壊斜面 Failed slopes & Slope A & Slope B & Slope E \\
\hline 地震時 During earthquake & & & 0.831 \\
安全率 Safety factor FS $(t=0)$ & 0.777 & 0.813 & 1.04 \\
$F S(t=5.8)$ & 0.856 & 0.908 & 1.55 \\
$F S(t=20.3)$ & 1.05 & 1.15 & 0.0352 \\
勾 配 Grad. of Fs vs. $t$ & 0.0137 & 0.0164 & 1.38 \\
\hline 常 時 Static condition & & & 1.67 \\
安全率 Safety factor FS $(t=0)$ & 1.26 & 1.34 & 2.41 \\
$F S(t=5.8)$ & 1.37 & 1.47 & 0.0509 \\
FS $(t=20.3)$ & 1.65 & 1.81 & 0.0234 \\
\hline
\end{tabular}

$t$ : 斜面単位断面幅のササ地下茎引張り力。 Tensile force of rhizome per unit sectional width of slope surface layer, $\mathrm{kN} / \mathrm{m}$.

0 (裸地) で地震時の 0.777 から大幅に増えて 1.26 と なり，常時にはササがなくても斜面は安定な状態で あることを示した。これにササの補強効果が加わる と, 安全率は $t$ の増加に伴って増加し, $t=5.0 \mathrm{kN} /$ $\mathrm{m}$ で 1.36 に $t=19.9 \mathrm{kN} / \mathrm{m}$ で 1.64 になった。地震 時の安全率 $0.845 \sim 1.05(t=5.0 \sim 19.9 \mathrm{kN} / \mathrm{m})$ より かなり大きくなり，斜面が安定な状態であることを 示している。式(1)'の $t$ に対する安全率の勾配は, 地震時の 0.0137 に対して 0.0192 と大きくなった。 一方, 斜面 Bでは常時の安全率は $t=0 \mathrm{kN} / \mathrm{m}$ で 1.34, $t=5.0 \sim 19.9 \mathrm{kN} / \mathrm{m}$ で $1.45 \sim 1.80$ になり,

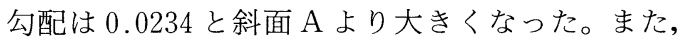
斜面 $\mathrm{E}$ では, 常時の安全率は $t=0 \mathrm{kN} / \mathrm{m}$ で 1.38 , $t=5.0 \sim 19.9 \mathrm{kN} / \mathrm{m}$ で $1.63 \sim 2.39$ になり, 勾配は 0.0509 と 3 斜面中最大であった。

\section{4. 考察}

4.1 表層崩壊についての安定解析モデルの安 全率

表層崩壊の解析モデルで斜面の安定性を表す, 安 全率 $F S$ と斜面単位幅断面の地下茎引張り力 $t$ との 関係を考察した。式(1)'の右辺第 2 項では崩壊土塊 の厚さ, その単位体積重量, 斜面の勾配や水平震度 係数が変わらなければ, $t=0 \mathrm{kN} / \mathrm{m}$ での Fs の切 片, すなわち裸地斜面の安全率は, 土の強度定数 $c$, $\tan \phi$ にっって決まる。裸地斜面は, ササに覆われる ことによって表層土にササ地下茥による引張り力が 発揮され, 斜面単位幅断面の引張り力が大きくなる ほど安全率が増加する。いわば，地下茎の補強効果
を式(1)' の勾配， $L /\left[S \cdot H \cdot \gamma_{\mathrm{t}} \bullet\left(\sin \alpha+K_{\mathrm{h}} \cdot \cos \alpha\right)\right]$ が示す。これは, 崩壊土塊の厚さ, その単位体積重量, 斜面の公配や水平震度係数が変わらなければ, 土塊 の破断長 $L$ と面積 $S$ によって決まる。一方で， $c$, $\tan \phi$ を変えて安全率を試算すると, わずかな違い によって值が大きく変わった。今回の試験から得た 土の強度定数を用いると地震時の安全率がたまたま 1.0 前後になったが，すべり面の土のせん断試験結 果は安定解析を行う上で重要であることを示した。 崩壊斜面の形状は，破断長 $L$ に違いをもたらす。 面積 $S$ がほとんど同じ斜面 $\mathrm{A}$ と $\mathrm{B}$ とでは半円形に 近い斜面 $\mathrm{A}$ が $L$ はdく，幅が小さく斜面長の長 い斜面 $\mathrm{B}$ は $L$ が大きくなる。また, 形状が半円形の 斜面 A と E とでは面積が異なる。その結果, 式(1)' の勾配は, 斜面 $\mathrm{A}, \mathrm{B}, \mathrm{E}$ の順に大きくなり，tの固 有值, 例えば $t=19.9$ で安全率を比較すると, それ ぞれ 1.64，1.80，2.39になった。すなわち，Sが大 きく $L$ が小さい斜面 $\mathrm{A}$ が最も崩壊しやすいことに なる。もしササ斜面全体が均一で諸条件が同じなら ば, 斜面 A のような形状と規模の崩壊が多く起こる ことになるが，自然斜面は地形，すべり面の土質条 件, ササの生育や地下茎分布, 樹木分布などの違い があって必ずしも均一でなく，こうした違いが崩壊 斜面の形状や面積の違いとなって表れると思われ る。

寒冷地の斜面表層土は, 凍上によって高含水率に なった凍土 ${ }^{7)}$ が春季に融解して部分的に過飽和状態 になり, 安全率に変化をもたらす。ササがつくり出 す熱環境によって，ササの稈密度が大きいほど凍結 
深や凍上量は小さくなる 幅断面の地下茎引張りカとの間に相関があるなら ば，安全率は $t$ が零に近いほど図 9 に示した常時の 安全率より実際には小さくなり，また $t$ が大きくな るにつれて常時の安全率に近づくであろう。しかし， 夏季には表層土の含水率も元に戻るため, $t$ が零近 くの安全率も図 9 の常時の状態に回復するであろ う。一方で，融雪水や降雨などによる表層土の緩み も凍結融解作用と同様に安全率を小さくすると考元 られる。このようにササ斜面は，種々の要因によっ て年間通じて安全率の変動はあるが，常にササの成 長によって安全率が回復するような機構になってい ると考えられ，長期間にわたって安定な斜面を形成 することになる。

ササ斜面の安定を論じてきた寒冷地は, 斜面を不 安定にする要因として温暖地で与えられるもの以外 に土の凍結融解という営力が加わり，より過酷な条 件下に置かれている。ここでの安定解析の結果は, 北海道のような寒冷地に限定されず，温暖地にも適 用されるものである。

4.2 植物根系の中でのササ地下茎の引張り強さ 斜面安定に寄与する植物の根系には, ササ類以外 に，大きく分けて草本類と木本類が挙げられるが, 引張り強さを実際の斜面に適用した研究は多くな い。木本類では，根系がすべり面でのせん断抵抗力 の増加をもたらすアンカー効果として評価され，安 定計算に根系の引き抜き抵抗力 ${ }^{8,211}$, 引き抜き抵抗 力を置き換えた林齢20) や引張り強さ21などの因子 が使われている。一方，今回のミヤコザサについて の安定計算では地下茎が土塊に対して斜面水平方向 の引張りカとして作用し，斜面単位幅断面の地下茎 引張り力の因子で表した。このように根系による斜 面安定の機構は異なるので，一律に両者の因子を比 較することは難しいが，過去の木本類の引張り強度 試験の值と比較した。著者らが室内試験で得たササ 地下茎の引張り強さは 8.4 33.8 MPa であった。他 のミヤコザサの值として $19.9 \mathrm{MPa}^{5,6)}$ (記載デー夕 から換算）が示されているが，これから室内試験の 結果が妥当なものであるとみなせる。木本類は種類 によって異なり, Pinus radiata 19.6 MPa, Douglas fir $49.0 \mathrm{MPa}^{14)}$ や, ウラジロモミ $35.9 \mathrm{MPa}$, アラカ シ $85.5 \mathrm{MPa}^{11)}$ などが示され, ササ地下茎は木本類 と比べてほぼ同等な值とみることができる。すなわ ち，ミヤコザサは木本類に匹敵する地下茎の引張り
強さを持って，斜面を覆っていることになる。

\section{5. まとめ}

ササ斜面の安定性を評価するため, 地震で崩壊し たササ斜面について表層崩壊に関する安定解析モデ ルを設定して, 現地調査や室内試験の結果および地 震情報を用いて安定解析を行った。その結果, 地震 時の安全率は, 斜面単位幅断面の地下茎引張り力の 関数として表すことができ，現地の崩壊状況を反映 したものであることが示された。地震時に用いた物 理定数を常時にも適用できると仮定して解析したと ころ, 常時の安全率は 1.26 以上となった。

調査・解析を通して，サ共斜面の表層崩壊に関わ るいくつかの因子を示した。ササの地下茎を一種の 斜面補強材料として扱い，表層土中の地下茎分布の 断面積と地下茎の引張り強さとから,「斜面単位幅 断面のササ地下茎引張り力」という変数を用いた。 この引張りカが安全率をどの程度変化させるのか, いわばササの斜面安定に及ぼす補強効果を定量的に 把握することが，本研究の目的の一つであった。ま た, 崩壊斜面周囲に沿って発揮される地下茎の引張 り力とすべり面の土のせん断抵抗力との定量的な違 いをグラフ上で示し，安全率に影響を及ぼす因子と して崩壊斜面の形状や面積を挙げて考察した。自然 のササ斜面に対して均一な条件を求めることは難し いが，実規模でのササ斜面について力学特性の概略 を表した。こうしたモデルは表層土の薄い切土斜面 を対象としたものに限られるが，円弧すべりを起こ す表層土の厚い切土斜面や盛土斜面では，ササマッ トのせん断抵抗力が抑止効果として働くものと考え られる。

本研究を遂行するにあたり, 舞鶴工業高等専門学 校中澤重一教授には多くの御助言を，また北見工業 大学伊藤陽司博士には地質情報の提供をいただき， ここに謝意を表する。

\section{引用文献}

1）土質工学会編：土質試験法（第 2 回改訂版），757 pp., 1979

2) Gray, D. H. and Megahan, W. F.: Forest vegetation removal and slope stability in the Idaho Batholith. USDA For. Serv. Res. Pap. Int-271, 11-19, 1981

3）榎 明潔：降雨時の斜面表層崩壊，土と基礎（地盤 
工学会), 47 (5), 17-20, 1999

4）地盤工学会編：切土法面の調査・設計から施工まで (地盤工学実務シリーズ 5), pp. 145-165，1998

5）苅住 昇：樹木根系図説, 誠文堂新光社, 1121 pp., 1979

6) 苅住 昇：ササ類の地下部の構造と土㙥緊縛力, Bamboo Journal, 4, 167-174, 1987

7）木下誠一編著: 凍土の物理学, 森北出版, pp. 3540, 1982

8）駒林富士弥・渡辺武夫 : 樹木の斜面安定効果, 日本 林学会誌, 59(9), 338-340, 1977

9) 小谷克巳 - 長岡信玄：斜面安定工法 (土木特殊工法 シリーズ)，森北出版，pp. 150-167，1984

10）強震観測事業推進連絡会議：1993 年 1 月 15 日平 成 5 年 (1993 年) 釧路沖地震, 強震速報 No. 41 (科 学技術庁防災科学技術研究所), p. 5, 1993

11）水島秀二・山辺正司：樹種別にみた樹木根系の抗張 力の検討, 第 28 回日本緑化工学会研究発表会研究 発表要旨集, 157-160, 1997

12）日本の地質「北海道地方」編集委員会編：日本の地 質 1, 北海道地方, 共立出版, pp. 113-114, 1990

13）大角恒雄・田中 弘・下倉 宏：道路盛土崩壊事例 に基づく切土斜面の地震時挙動に関する一考察, 第 22 回地震工学研究発表会, 139-142, 1993

14) O'Louglin, C. L. and Ziemer, R. R.: The importance of root strength and deterioration rates upon edaphic stability in steepland forests. Proceedings of IUFRO Workshop, P. I. 07-00 Ecology of Subalpine Zones, Corvallis, OR. 70-78, 1982

15）札幌管区気象台編：北海道気象月報 1992 年 11 月 ～1993 年 4 月，1992 1993

16）武田一夫・岡村昭彦・伊藤隆広：寒冷地における法 面保護工の開発 ( I ) 法面凍上害の分布とその発生 過程，日本緑化工学会誌，25(1)，1-12，1999

17）武田一夫・岡村昭彦：寒冷地におけるササの形成す る熱環境，日本緑化工学会誌，25(2)，91-101，1999

18）武田一夫・岡村昭彦・伊藤隆広：寒冷地における法 面保護工の開発 (II) 凍上抑制法枠の考案と現地試 験，日本緑化工学会誌，26(1)，6-17，2000

19）土岐祥介・三浦均也・山下 聡：1993 年釧路沖地震 における被害の概要，土と基礎，41(6)，報文 2257 , 5-10, 1993

20）塚本良則：樹木根系の崩壊抑止効果に関する研究, 東京農工大学農学部演習林報告, 第 23 号, 65-124, 1987

21) Wu, T. H., Mckinnell III, W. P. and Swanston, D. N.: Strength of tree roots and landslide on Prince of Wales Island. Alaska, Can. Geotech. J., 16, 19-33, 1979

(2000. 9. 30 受理)

\section{Summary}

In order to evaluate the surface stability of a slope covered with Sasa nipponica, we conducted field surveys of the surface failures in places on the wild slope that were considered to be caused by an earthquake. We also conducted laboratory tensile tests of the rhizome, and laboratory soil tests. Since the field surveys of the slope showed that the surface failures have an integrative pattern, we set up an analytical model of the stability of the slope against surface failures, and calculated the stability of the slope by using the observed intensities of the quake applied to the slope, and the survey and laboratory test results. As a result, the safety factors of the slope expressed as a function of the total rhizome tension per lateral sectional unit width of slope surface layer were about 1.0, indicating that the surface failures were caused by the earthquake in places on the slope. Assuming that the physical constants used in the calculation are all reasonable, the safety factor in a static condition exceeded 1.26 everywhere on the slope. The equation of this analytical model indicates that an increase of the safety factor of the slope through the total rhizome tension per lateral sectional unit width of the slope verifies the positive effect of the rhizome of the Sasa nipponica on the reinforcement of the slope against the surface failures, and that, in contrast, the safety factors of the slope without dwarf bamboo depend mainly on the strength parameters of the soil in the sliding layer. Further, as the surface failure pattern changed from that of a semicircular to one that is longer longitudinally along the slope and the area of the surface failure became smaller, the safety factor of the slope became greater. 